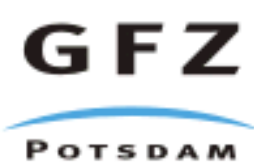

Originally published as:

Bräuer, B., Ryberg, T., Lindeque, A. S. (2007): Shallow seismic velocity structure of the Karoo Basin, South Africa. - South African Journal of Geology, 110, 2-3, 439-448,

DOI: 10.2113/gssajg.110.2-3.439 


\title{
Shallow seismic velocity structure of the Karoo Basin, South Africa
}

\author{
Benjamin Bräuer and Trond Ryberg \\ GFZ - GeoForschungsZentrum Potsdam, Telegrafenberg 14473, Potsdam, Germany \\ e-mail: ben@gfz-potsdam.de; \\ Ansa S. Lindeque \\ GFZ - GeoForschungsZentrum Potsdam, Telegrafenberg 14473, Potsdam, Germany \\ CGS - Council for Geoscience, Western Cape, P.O. Box 572, Bellville 7535, Cape Town, South Africa \\ AEON - Africa Earth Observatory Network and Department of Geological Sciences, \\ University of Cape Town, Rondebosch 7701, South Africa \\ e-mail: ansali@gfz-potsdam.de or alindeque@geoscience.org.za
}

(C) 2007 September Geological Society of South Africa

\begin{abstract}
A Near Vertical Reflection (NVR) Seismic profile from Prince Albert to Slingersfontein across the Karoo Basin of South Africa was generated using 182 controlled source shots at $\sim 500 \mathrm{~m}$ spacing and receiver points at $100 \mathrm{~m}$ nominal spacing in an $18 \mathrm{~km}$ spread. Travel time data of seismic phases are used as input data to derive shallow velocity models of compressional waves (P) and shear waves (S). Using First Arrival Seismic Tomography (FAST) software, we derive shallow tomographic P- and S-velocity models for the upper 1 to $1.5 \mathrm{~km}$. Checkerboard tests indicate good resolution down to $1 \mathrm{~km}$ depth. The models of P- and S-velocity and $\mathrm{Vp} / \mathrm{Vs}$ ratio show an abrupt change at $\sim 50 \mathrm{~km}$, dividing the model into two regions. A southernmost region consists mainly of steeply dipping in-situ sedimentary bedrock with an east-west strike, approximately perpendicular to the profile. The northern $50 \mathrm{~km}$ region comprises predominantly unconsolidated sediment and/or highly weathered rock, yielding a high $\mathrm{Vp} / \mathrm{Vs}$ ratio. The tomographic models compare well with corresponding lateral variation in the surface geology of the Permian Karoo Supergroup sedimentary rocks (Dwyka, Ecca and Beaufort Groups) deformed at the Cape Fold Belt front. The correlation between the velocity models and outcrops is stronger for the southernmost $25 \mathrm{~km}$ of the NVR seismic profile. Although the surface geology is more uniform from kilometre 25 to 50 , the velocity models and $\mathrm{Vp} / \mathrm{Vs}$ ratio suggest continued systematic lateral variation. Based on this, we infer a sub-surface continuation of tight folding not seen in outcrops. The S-velocity model supports this theory, as velocity variations correlate well with the location of major fold axes in the regional scale gentle tight folding of the Ecca Group (Abrahamskraal Formation). In the northern part of the model, from 50 to $100 \mathrm{~km}$, minimal change in the velocity models indicate more uniform and undisturbed lithologies.
\end{abstract}

\section{Introduction}

A $100 \mathrm{~km}$ Near Vertical Reflection (NVR) Seismic profile from Prince Albert to Slingersfontein (Lindeque et al. 2007), shown in Figure 1, forms part of a much longer onshore-offshore Inkaba yeAfrica Agulhas-Karoo Geoscience Transect (de Wit and Horsfield, 2006). Other datasets along this middle $\sim 100 \mathrm{~km}$ segment comprise wide angle tomographic inversion of the crust to $30 \mathrm{~km}$ depth (Stankiewicz et al. 2007) and magnetotelluric data crossing the Beattie Magnetic Anomaly (Weckmann et al. $2007 a$; b). Here, we report on velocity tomography studies in the upper $1 \mathrm{~km}$, derived from the NVR seismic data.

The data acquisition layout consisted of 180 receivers with $\sim 100 \mathrm{~m}$ spacing distributed over a spread length of $\sim 18 \mathrm{~km}$ and a total of 182 shots long the $\sim 100 \mathrm{~km}$ profile. Each day 8 shots were completed every second kilometer, creating an asymmetric split-spread shooting geometry. On subsequent days, 36 receivers were moved from the tail-end to the front of the spread, in a roll-along procedure. An average shot spacing of $0.5 \mathrm{~km}$ and a maximum offset of $16 \mathrm{~km}$ were maintained.

We use a 2-D tomographic inversion code FAST (First Arrival Seismic Tomography, Zelt and Barton, 1998) to obtain a detailed tomographic image of the shallow velocity structure under the Karoo Basin, using the travel times between the sources and receivers. We limit our focus to the upper 1 to $2 \mathrm{~km}$ of the Karoo Basin.

\section{Geological Setting}

The NVR seismic profile crosses the $\sim 4 \mathrm{~km}$ thick siliciclastic Carboniferous to Jurassic shale, siltstone and sandstones strata of the Karoo Basin. The southern part was deformed at $\sim 250 \mathrm{Ma}$ during the Cape Fold Belt orogeny (Hälbich, 1993). Details of the Karoo Basin stratigraphy, sedimentology, structure and palaeoenvironments can be found elsewhere (Visser, 1987; Visser, 1992; Cole, 1992; Wickens, 1992; Johnson et al. 1997; Catuneanu et al. 1998). Surface lithologies encountered along the NVR profile are depicted in a simplified geology map (Figure 2) and Table 1. From oldest to youngest, the profile crosses the Dwyka Group, Ecca Group and the Abrahamskraal Formation of the Beaufort Group, ending in the Karoo Dolerites. Along the southern $30 \mathrm{~km}$ of the profile, the Karoo rocks are deformed into north-verging tight to isoclinal folds at the Cape Fold Belt front, and at surface, limbs are often steeply dipping and overturned. Northwards, these structures grade into gentler open folding and the 


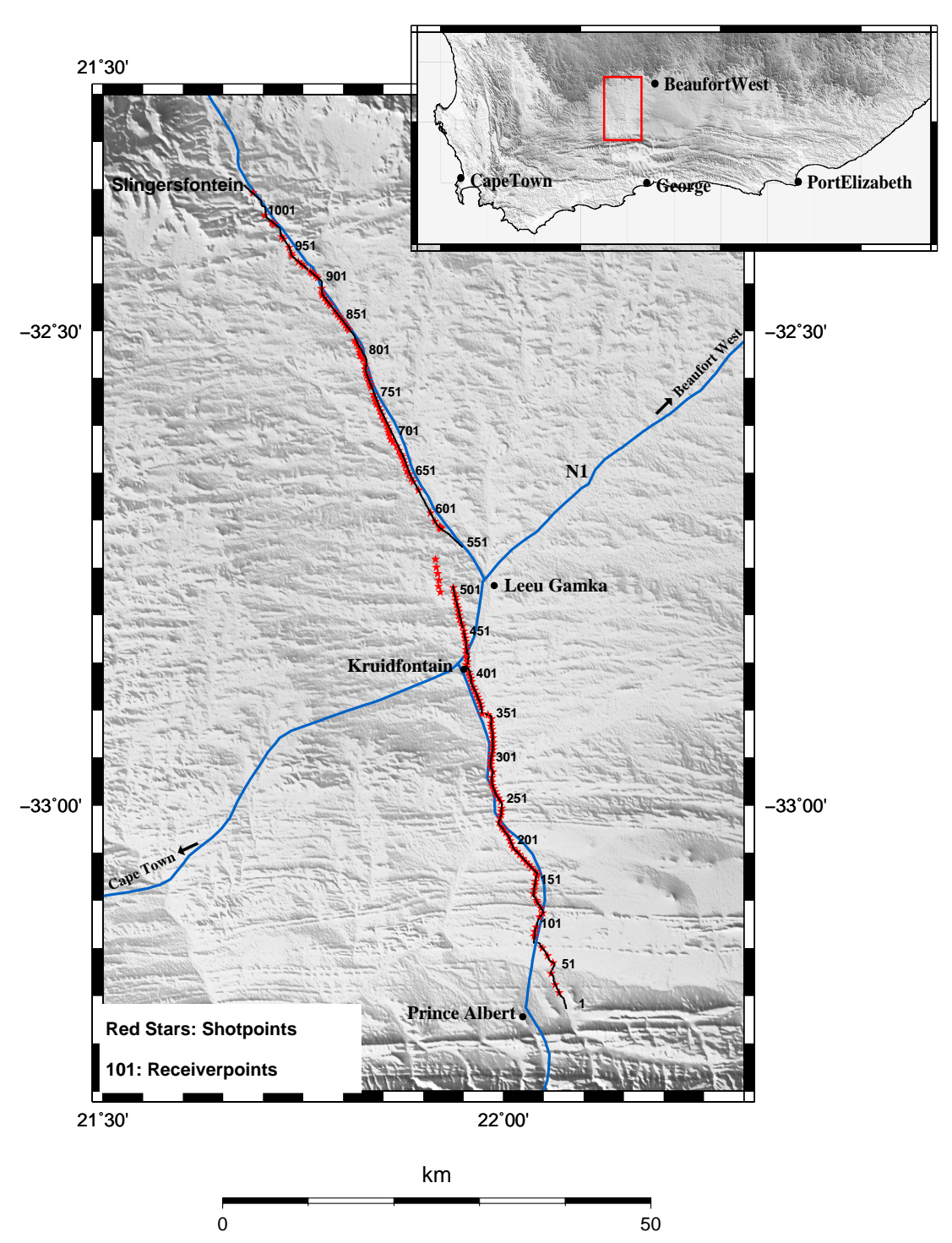

Figure 1. Location of the Near Vertical Reflection Seismic profile from Prince Albert to Slingersfontein, on a $90 \mathrm{~m}$ digital elevation topography model. Blue $=$ national roads; black = receivers; red = sources. Insert shows regional setting of the profile $($ red box) .

Table 1. Simplified stratigraphy along the NVR transect shown in the geological map (Figure 2), from the 1:1 000000 geological map sheet series Council for Geoscience (Volquardsen et al., 1984)

\begin{tabular}{|c|c|c|c|c|c|}
\hline Age & & Group & Formation & Key & Description \\
\hline Jurassic & Karoo Supergroup $(\sim 4604 \mathrm{~m})$ & Dolerites & Karoo Dolerites & Jd & Crystalline sills and dykes \\
\hline \multirow[t]{9}{*}{ Permian } & Karoo Supergroup $(\sim 4604 \mathrm{~m})$ & Beaufort & Abrahamskraal & $\mathrm{Pa}$ & Mudstone, sandstone and thin chert beds \\
\hline & Karoo Supergroup $(\sim 4604 \mathrm{~m})$ & Ecca & Waterford & $\mathrm{Pw}$ & Dark grey carbonaceous shale \\
\hline & & & Fort Brown & Pf & Shale rythmite \\
\hline & & & Ripon & $\operatorname{Pr}$ & Mottled grey sandstone and shale \\
\hline & & & Vischkuil & & Arenaceous shale and subordinate sandstone \\
\hline & & & Collingham & & Rhythmically bedded gray shale and thin tuff \\
\hline & & & Whitehill & & White weathering black shale with chert \\
\hline & & & Prince Albert & & Greenish gray shale \\
\hline & Karoo Supergroup $(\sim 4604 \mathrm{~m})$ & Dwyka & & $\mathrm{Pd}$ & Glacial diamictite deposit - tillites and shales \\
\hline \multirow[t]{2}{*}{ Devonian } & Cape Supergroup & Witteberg & & Dw & Shale with sandstone and siltstone \\
\hline & & & & & Quartzitic sandstone \\
\hline
\end{tabular}




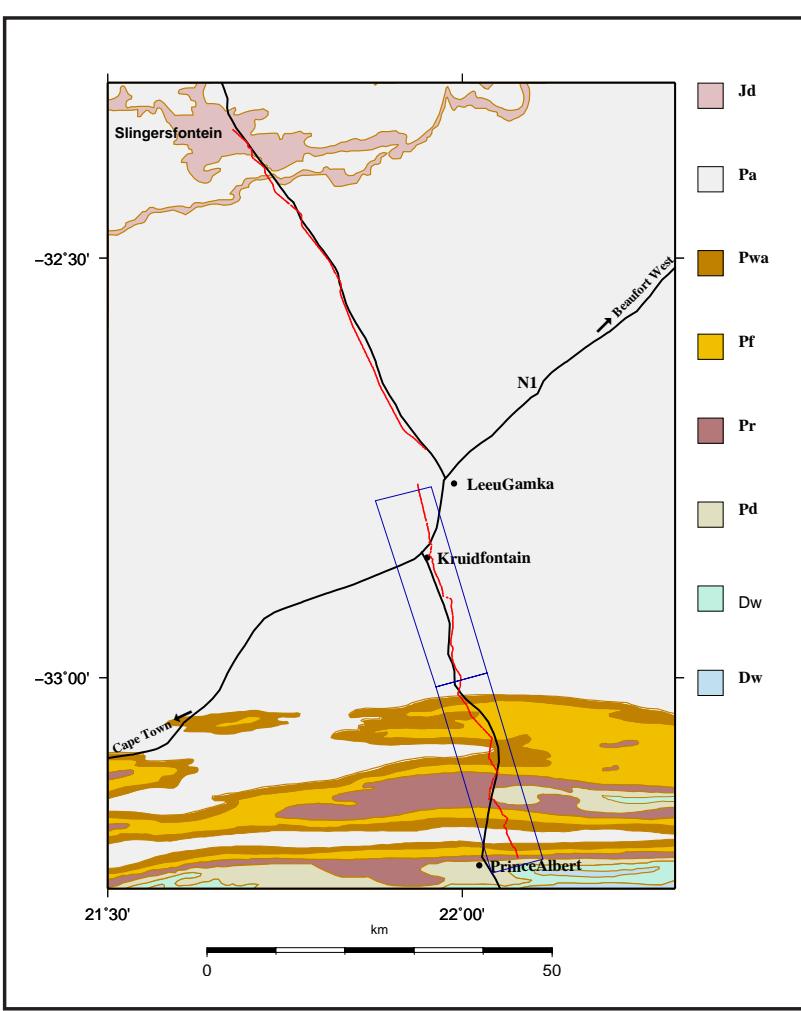

Figure 2. Simplified geological map of the profile area. Red = Receiver line, black = national roads. The rectangles depict the areas shown in Figures 8 to 10. Geology taken from the Geological Map of South-West Africa (Volquardsen et al., 1984). Explanation of the different lithological units is given in Table 1. succession is near horizontal at the northern end of the profile.

Data Processing and Tomographic Inversion In total, 26858 first P-wave arrivals and 12216 first S-wave arrivals were manually picked. The quality and the number of the S-wave travel time picks is lower than that for the P-waves. This may be because S-wave first arrivals are not easily recognized in the raw data due to interactions with the P-coda, the ground roll and converted phases (Figure 2).

Figure 3 illustrates a typical example of the raw data for one shot with first breaks of the P-waves (Figure 3a) and the S-waves (Figure 3b) clearly visible. The estimated picking error is $\sim 5 \mathrm{~ms}$ for P-arrivals and $\sim 20 \mathrm{~ms}$ for S-arrivals. Characteristic frequencies of the P-waves are about $25 \mathrm{~Hz}$. With an average P-wave velocity of $\sim 5 \mathrm{~km} / \mathrm{s}$ (Figure 4) their wavelength is $\sim 200 \mathrm{~m}$. The average frequency of the S-waves is 10 to $12 \mathrm{~Hz}$ and the average S-wave velocity of $2.6 \mathrm{~km} / \mathrm{s}$ results in wavelengths of $\sim 200 \mathrm{~m}$ as well.

Given the profile length, source/receiver spacing and ray coverage, seismic velocities were sampled by shallow rays down to maximum depths of 1 to $1.5 \mathrm{~km}$. This shallow penetration can be explained by high rock velocities at the surface (e.g., $4.4 \mathrm{~km} / \mathrm{s}$ for the P-waves) and a consequentially weak vertical velocity gradient.

The two-dimensional version of the inversion code FAST by Zelt (1998) and Zelt and Barton (1998), was

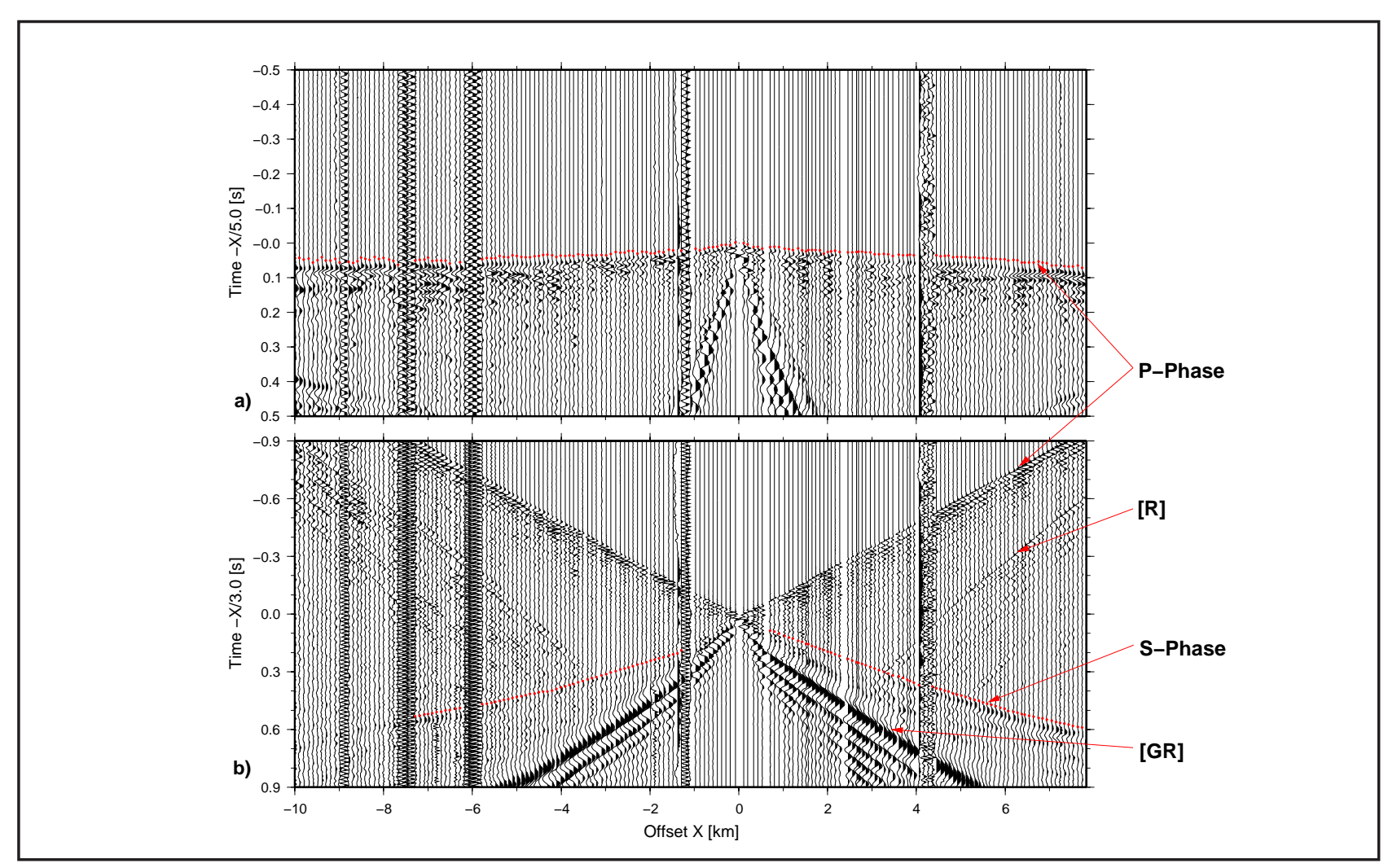

Figure 3. Raw data for shot point 141 with the P-wave and S-wave picks (red dots). (a) Shot-record highlighting the P-waves with reduction velocity of $5 \mathrm{~km} / \mathrm{s}$; (b) Shot-record highlighting the S-waves with reducing velocity $3 \mathrm{~km} / \mathrm{s}$. Reflections (R) and ground roll (GR) are annotated. 


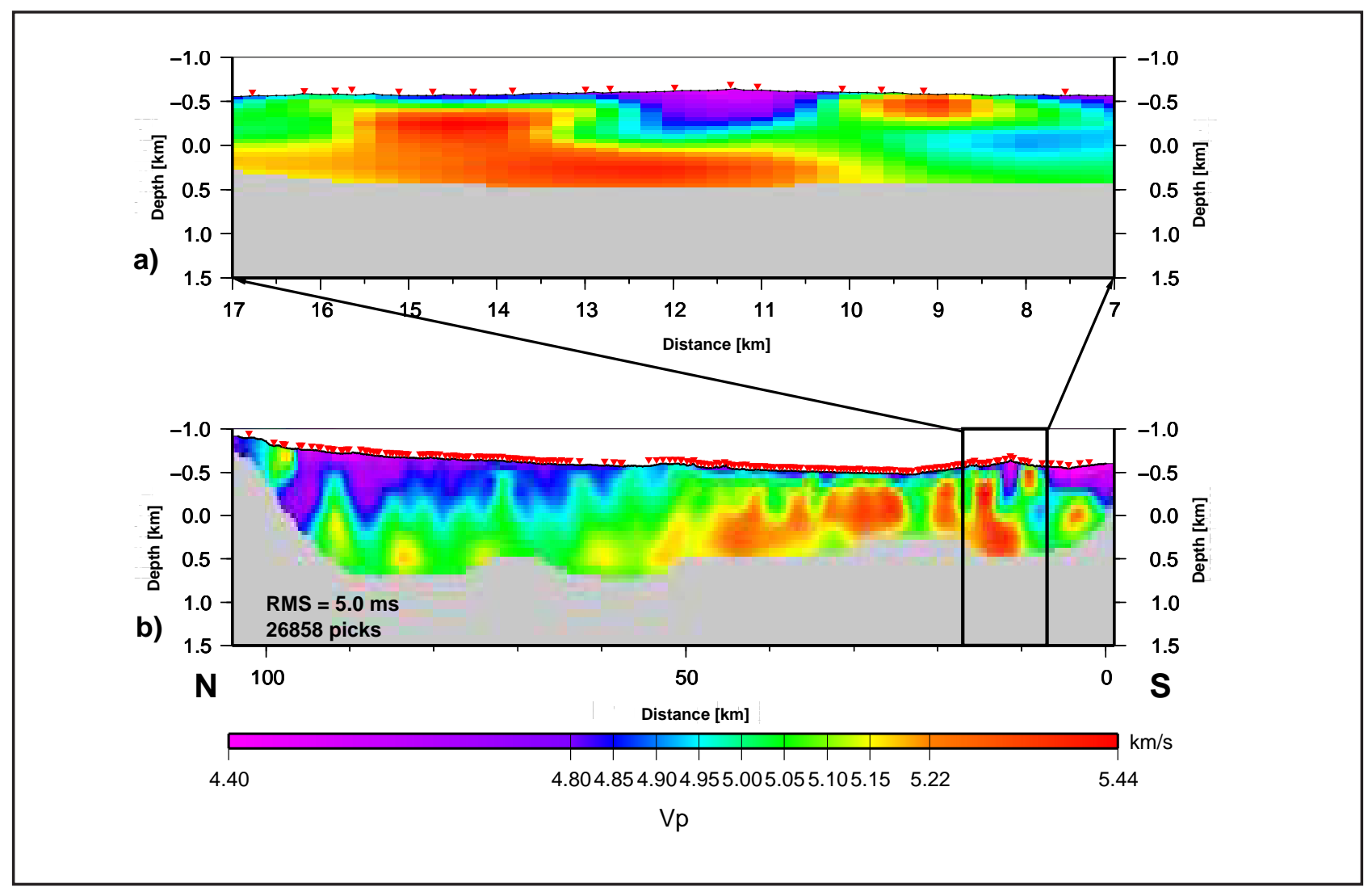

Figure 4. P-wave velocity model. (a) Section between 7 and $17 \mathrm{~km}$ with a vertical exaggeration of 1:1 and (b) Complete model for the P-waves with ten times vertical exaggeration. Red triangles are the shot points. Regions with hit counts below 30 have been blanked out.

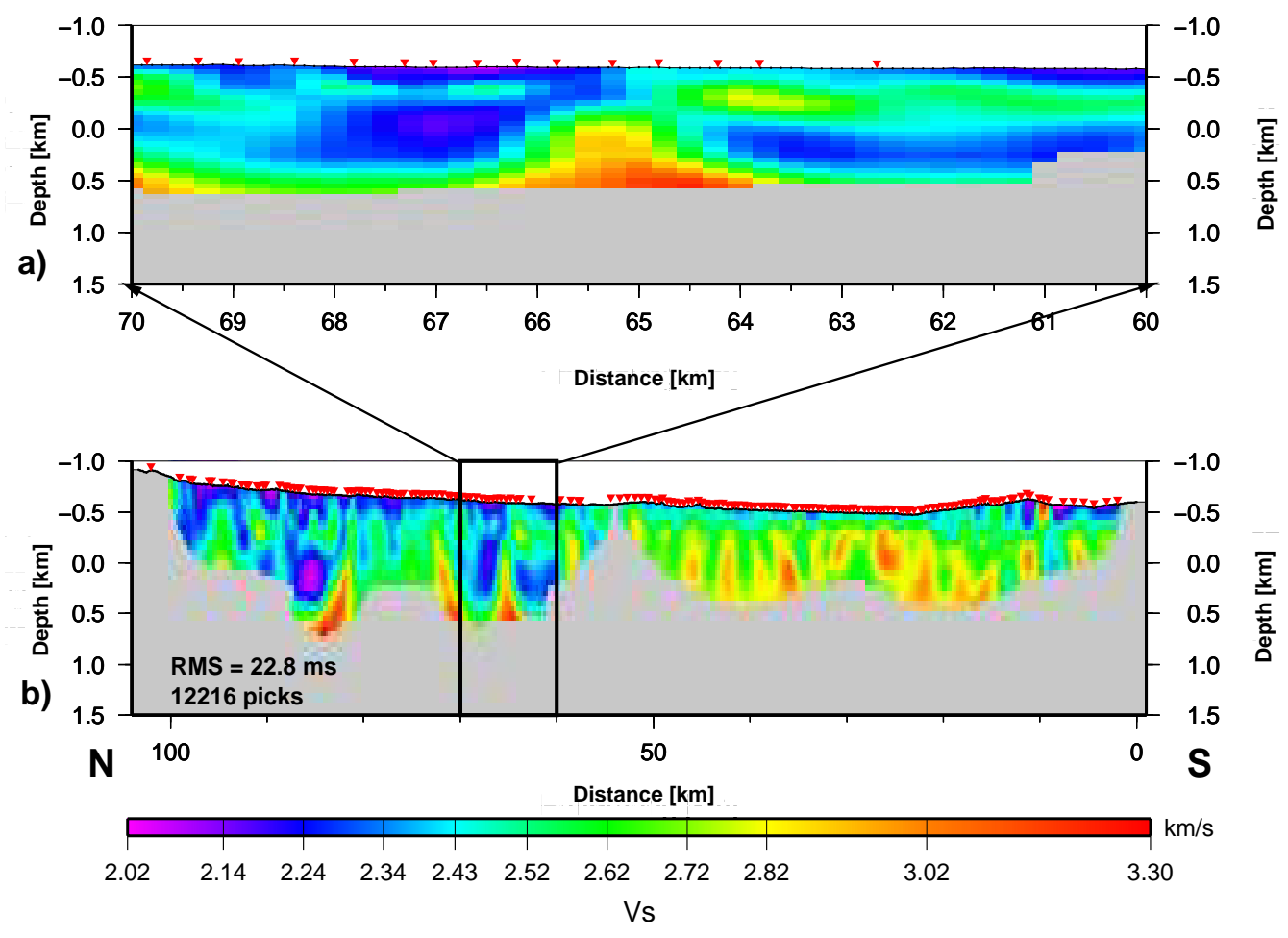

Figure 5. S-wave velocity model (a) Section from kilometer 60 to 70; (b) Entire section (vertical exaggeration = 1:10). Red triangles represent the shot points. Regions with hit counts below 30 are blanked out. 

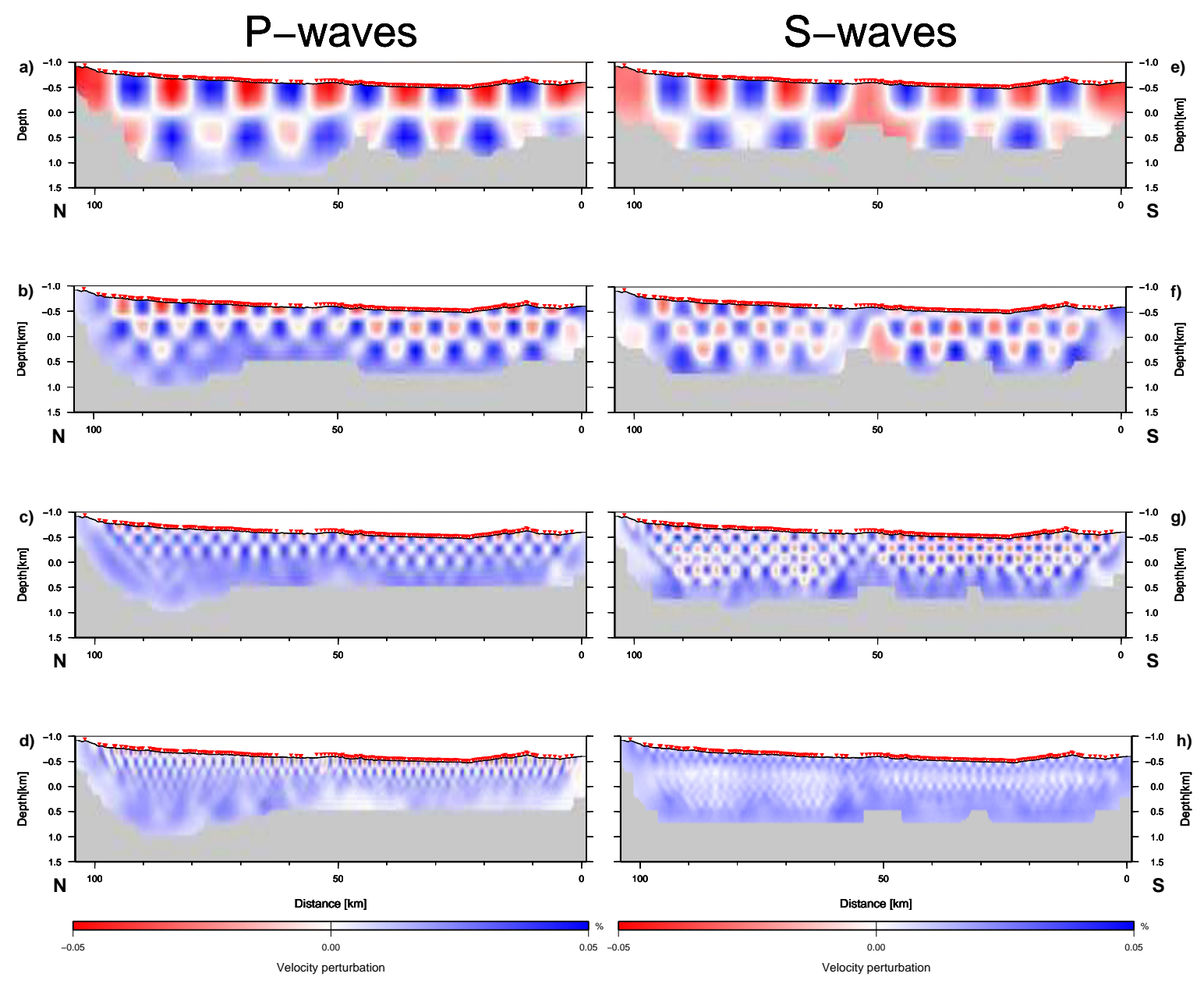

Figure 6. The checkerboard tests results of the P- (a-d) and the S-waves (e-h) for various block-sizes: (a,e) 8 x 1 km (b,f) 4 x 0.4 km (c,g) $2 \times 0.2 \mathrm{~km}(\mathrm{~d}, \mathrm{~h}) 1 \times 0.1 \mathrm{~km}$. Vertical exaggeration $=1: 10$.

used to derive a velocity model based on travel time data. For this, the shot and receiver locations were projected onto a straight line calculated by linear regression. The Vidale (1988; 1990) scheme was modified to handle large velocity contrasts according to the method of Hole and Zelt (1995; see Stankiewicz et al. 2007 for more details) and then used for the forward calculation of travel time and ray paths. The cross-section beneath the length of the profile was divided into rectangular blocks (e.g., Ryberg et al. 2006) for calculation of the tomographic inversion model.

To derive a robust inversion model, we used an iterative approach of varying cell sizes as developed by Ryberg et al. (2007). The inversion starts with large block sizes $(5 \times 0.5 \mathrm{~km})$ and the result of this first inversion is used as a starting model to invert for finer-scaled model (block size: $2.5 \times 0.25 \mathrm{~km}$ ). This procedure is repeated four times, yielding a final inversion block size of $0.25 \mathrm{x}$ $0.05 \mathrm{~km}$. The final P-wave-model is characterized by a root-mean-square (RMS) travel time misfit of $\sim 5 \mathrm{~ms}$ for 26,858 travel time picks. This inversion technique, results in a very stable final model in which the appearance of tomographic artifacts are minimized.
An S-wave velocity model was obtained using the same procedure, with a final RMS misfit of $\sim 23$ ms for 12216 travel time picks. This is $4-5$ times higher than the RMS misfit of the P-wave model.

\section{Results and Reliability}

The P-wave velocity model is shown in Figure 4. The overall velocities range between 4.40 and $5.44 \mathrm{~km} / \mathrm{s}$. In the southern part of the profile, the velocities are higher, varying between 5.0 to $5.44 \mathrm{~km} / \mathrm{s}$. The model changes abruptly at $\sim 50 \mathrm{~km}$ and from there, the velocities are significantly slower ( 4.40 to $4.95 \mathrm{~km} / \mathrm{s}$ ) up to the end of the profile.

Figure 5 illustrates the S-wave velocity model. The result compares well with the P-wave model. Velocities in the southern $50 \mathrm{~km}$ of the S-wave model are high and range from $2.62-3.30 \mathrm{~km} / \mathrm{s}$. An abrupt change is observed also at $\sim 50 \mathrm{~km}$ along the profile, after which the velocities are lower ( 2.02 to $2.72 \mathrm{~km} / \mathrm{s}$ ) along the northern section of the profile.

Checkerboard tests are used to evaluate the resolution of the two different velocity models (Figure 6). In these tests, a simple checkerboard 


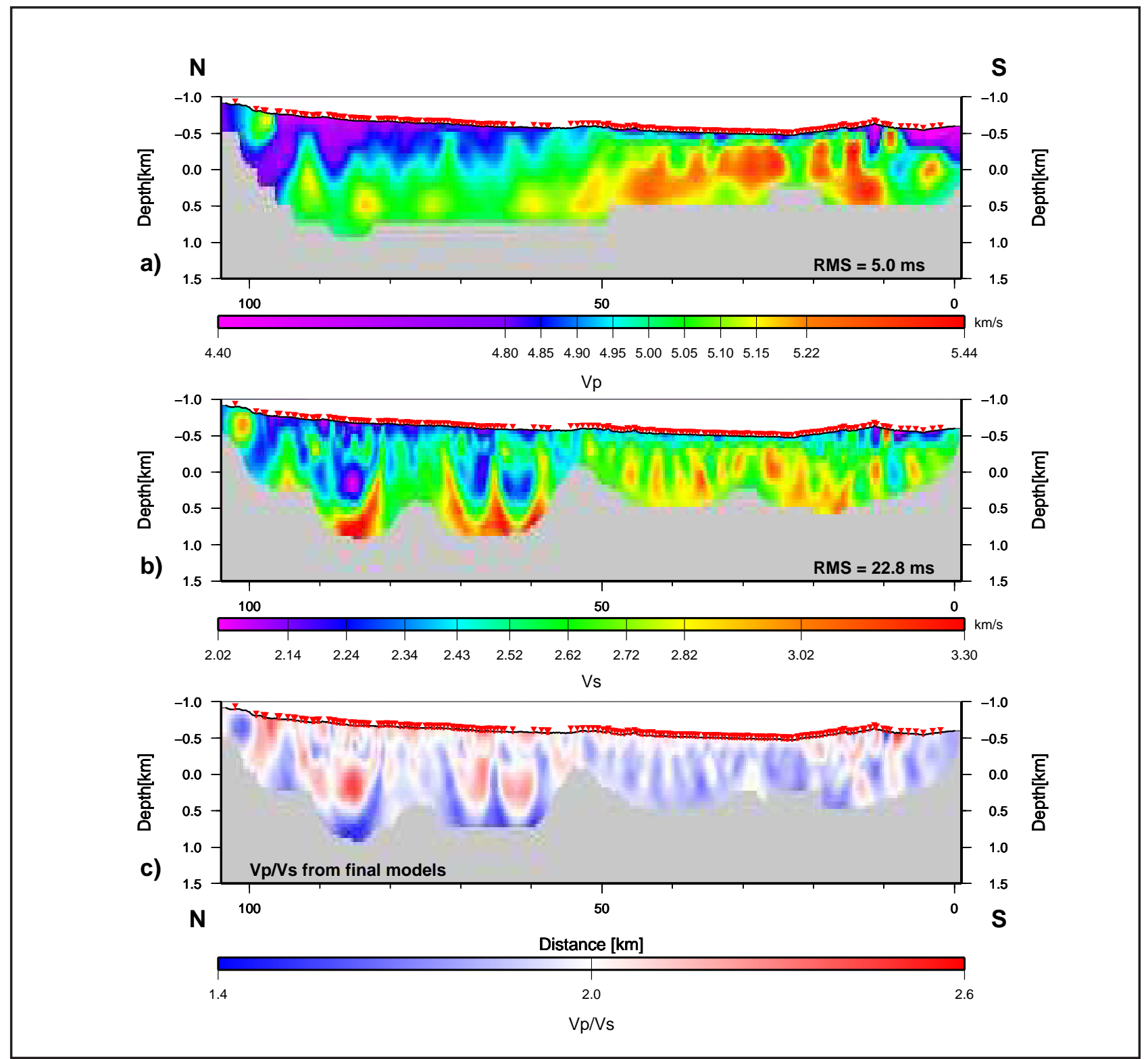

Figure 7. (a) P-wave model (b) S-wave model and (c) Vp/Vs ratio model along the $\sim 100 \mathrm{~km}$ profile. Note the distinct change in the velocity structure at about $50 \mathrm{~km}$ along the profile. No vertical exaggeration.

synthetic velocity model with $5 \%$ velocity perturbations is overlain on a 1-D-background model. Synthetic travel times are calculated for the actual ray coverage provided by the P-wave (Figures $6 a$ to $\mathrm{d}$ ) and the S-wave (Figures be to h) models, and the inversion is then applied using different block sizes. This inversion result is compared to the initial checkerboard model. If the original blocks are recovered in the final model, it means that features of the checkerboard block size are resolvable and not a processing artifact. For example, the relatively high velocities observed between kilometer 60 and 90 at $0.5 \mathrm{~km}$ depth in the Vs model (Figure 5) should be regarded with caution since the checkerboard tests in Figure 6 indicate poorer resolution at this position and depth. In the P-wave velocity model, the checkerboard tests demonstrate that $8 \mathrm{~km}$ wide features are resolved to $1.5 \mathrm{~km}$ depth and $1 \mathrm{~km}$ wide features are resolved to a depth of $\sim 500 \mathrm{~m}$ (Figure 6).
The ratio between the $\mathrm{P}$ - and $\mathrm{S}$-wave velocities $(\mathrm{Vp} / \mathrm{Vs})$ is an important parameter for further interpretation as it gives insight into the physical properties of the rock strata. This ratio is illustrated in Figure 7. Higher $\mathrm{Vp} / \mathrm{Vs}$ ratios of 1.9 to 2.5 occur mostly in the northern part of the profile, while lower values of 1.6 to 2.2 are observed in the southern part of the profile. The low $\mathrm{Vp} / \mathrm{Vs}$ values of about 1.4 in the northern part at $\sim 0.5 \mathrm{~km}$ depth are related to the extremely high Vs values at greater depth and are therefore uncertain. Again as seen in the Vp and Vs models, an abrupt change at $\sim 50 \mathrm{~km}$ along the profile is evident. The change at the $50 \mathrm{~km}$ region thus appears confined to the upper 1 to $1.5 \mathrm{~km}$ of the crust.

\section{Discussion}

The velocity models and $\mathrm{Vp} / \mathrm{Vs}$ ratio indicate that the profile, and by implication the uppermost zone of 


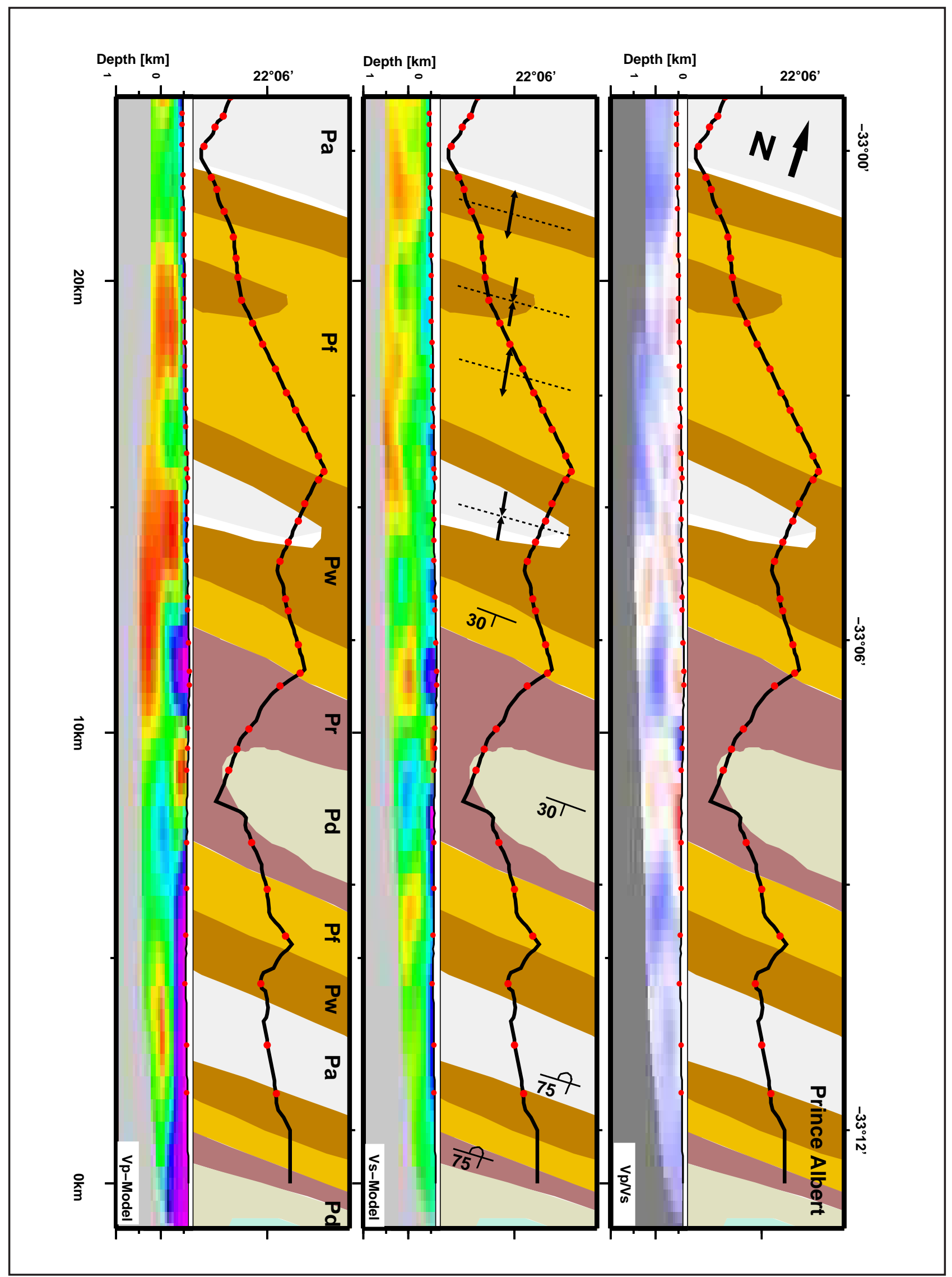

Figure 8. Velocity model sections plotted against the geology map along the southernmost $25 \mathrm{~km}$ of the NVR seismic profile. Black line $=$ receiver line; red dots = shot points. The geology colour codes are the same as in Figure 2: $\mathrm{Pd}=$ Dwyka Group, $\mathrm{Pr}=\mathrm{Prince}$ Albert, Whitehill, Collingham, Vischkuil and Ripon Formations, $\mathrm{Pf}=$ Fort Brown Formation, $\mathrm{Pw}=$ Waterford Formation, $\mathrm{Pa}=$ Abrahamskraal Formation The colour-coded velocity scales are the same as in Figure 7. Width of the geology strips $\sim 2 \mathrm{~km}$. 


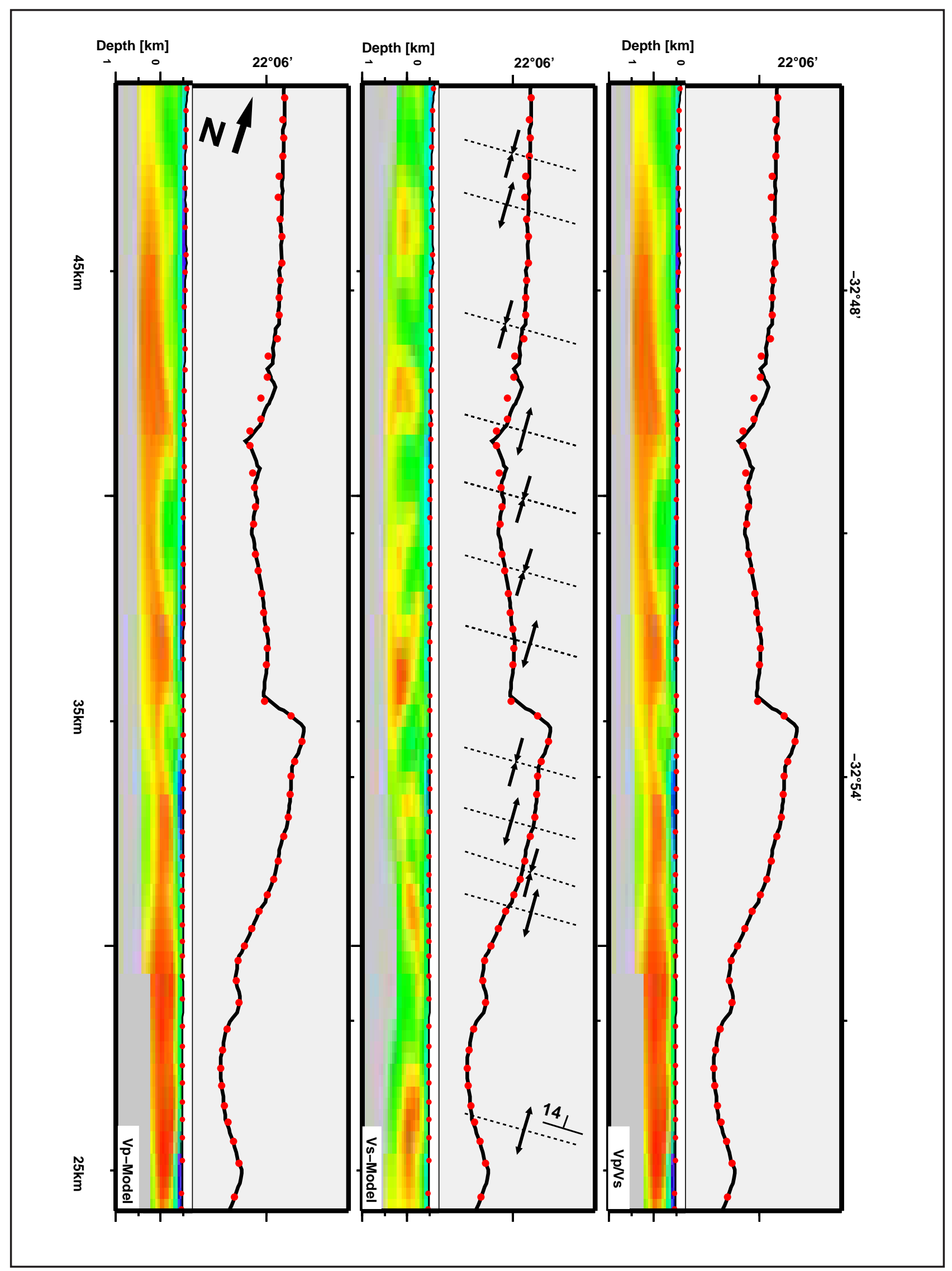

Figure 9. Comparison of the velocity models with the geology, from $25-50 \mathrm{~km}$ along the profile. Black line $=$ receiver line; Red dots $=$ shot points. The geology colour codes are the same as in Figure 2 and 8 . Note the correspondence between synclinal fold axes and S-velocity lows (green-blue), and anticline axes to high S-velocities (yellow-red). Fold axes and dip information were independently mapped and taken from 1:250000 Geological map sheets 3220 Sutherland and 3322 Oudtshoorn published by the Council for Geoscience. 


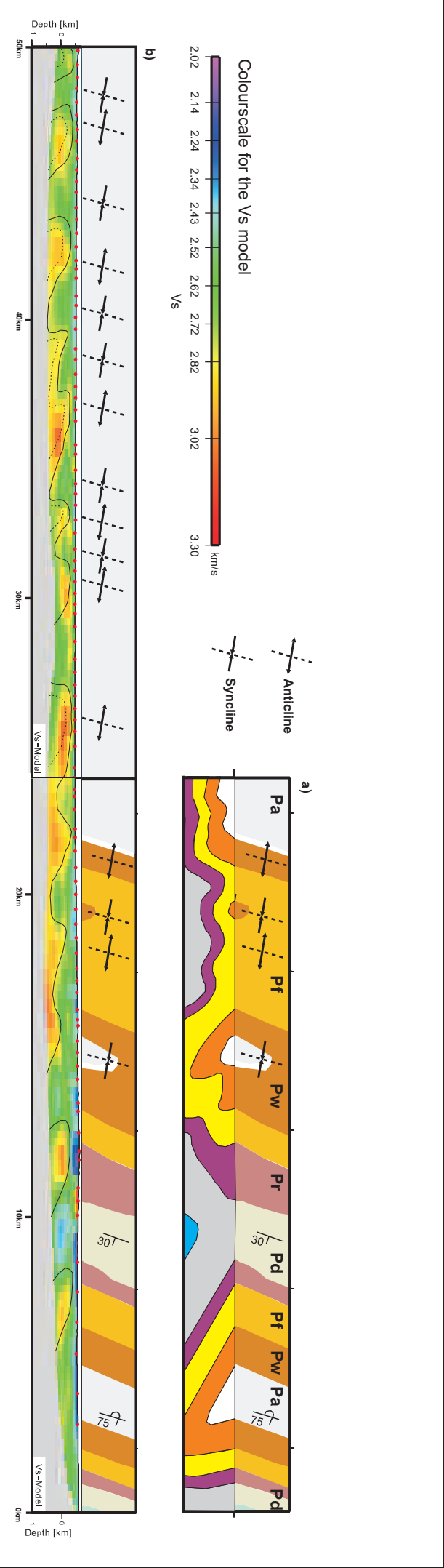

Figure 10. (a) 3-D Geological model derived from strike and dip information on geological maps (b) Vs model with superimposed interpretation of geological structures for the southernmost $50 \mathrm{~km}$ of the profile, in which high Vs correspond to anticlines and low Vs to synclines. Note the similarities and differences between $\mathrm{a}$ and $\mathrm{b}$. the southern Karoo Basin, can be divided in two parts. The southern part is characterized by high velocities in the P- and S-wave models and the velocity structure is heterogeneous. We interpret this to reflect a complex structural region with significant lateral lithology variation. In the northern part, a low and more homogeneous velocity structure is present, which we interpret to reflect a simple structural region of more uniform lithology.

The $\mathrm{Vp} / \mathrm{Vs}$ ratio model can be subdivided in a similar way. In the south the ratio is below $2(\sim 1.7$ on average), which is typical of unweathered bedrock. In contrast the northern section has ratios predominantly greater than or equal to two, except in the area of the anomalous high $\mathrm{S}$-wave velocities at the lower edge of the model. $\mathrm{Vp} / \mathrm{Vs}$ ratios greater than or equal to two are characteristic of unconsolidated sediments.

Because the tomography provides a well-resolved image of the first kilometer of crust, we look for correlations and/or discrepancies with the known surface geology in the areas depicted in the boxes in Figure 2, the southernmost $50 \mathrm{~km}$ of the profile.

Possible correlations between the velocity models and the geology are tested in Figures 8 and 9. We note a close correlation between the surface geology, velocity models and $\mathrm{Vp} / \mathrm{Vs}$ ratio in the southernmost $25 \mathrm{~km}$ of the profile (Figure 8). Velocities of the Vp and Vs models vary systematically along the profile and appear to correspond with lateral changes in the lithologies of the Dwyka and Ecca Groups (Prince Albert, Whitehill, Collingham, Vischkuil, Ripon, Fort Brown, Waterford and Abrahamskraal Formations), repeated by folding. These systematic velocity variations may be due to different degrees of weathering or known lithological variations within the formations. Note that the glacial Dwyka Formation shows a distinctly higher velocity on the Vp model, probably because it has a denser matrix than that of the adjacent sedimentary rocks of the Ecca Group.

From kilometer 25 to 50 , the surface lithology is dominated by the gentle folded Abrahamskraal Formation. Figure 9 is a plot of the location of major fold axes, the $\mathrm{P}$ - and S-velocity models and $\mathrm{Vp} / \mathrm{Vs}$ ratio. We note a reasonable correlation between the geological structures and the seismic tomography. The velocity models, especially the S-wave model, suggest therefore that the fold structures seen in Figure 8 continue below surface up to kilometer 50 . We illustrate this hypothesis in Figure 10. The geological model in Figure 10a is independently derived from existing geological maps. If we compare the Vs model and geologic interpretations in Figure 10b, the first $25 \mathrm{~km}$ changes in the surface geology correlates well with the velocity variations. Furthermore, we observe that the anticline fold axes mapped from surface geology corresponds reasonably well with high velocity zones in the Vs model and the synclines correspond with low S-velocities (b). We may therefore infer that complex tight folding continues after 
kilometer 50, beneath the more gently folded shales and sandstones of the Abrahamskraal Formation.

\section{Conclusions}

The near-surface velocity structure down to depth of 1 to $1.5 \mathrm{~km}$ along a NVR seismic profile from Prince Albert to Slingersfontein across the Karoo Basin was determined from first arrivals of P- and S-waves. Four main conclusions are drawn from this:

- The profile is divided in two regions: the first $50 \mathrm{~km}$ comprises predominantly near surface bedrock and the second $50 \mathrm{~km}$ region comprises a predominantly thicker layer $(>1 \mathrm{~km})$ of unconsolidated or highly weathered strata.

- The exact cause of the abrupt transitions in both the Vp and Vs models at $50 \mathrm{~km}$ is not clearly understood.

- The lateral variations in velocity models correlate well with folding of the rock strata seen in outcrop geology of the southernmost $25 \mathrm{~km}$.

- The models suggest a sub-surface continuation of similar folds up to $50 \mathrm{~km}$, where they are overlain by more gently folded to near horizontal strata of younger sequences.

\section{Acknowledgements}

The authors would like to thank all the participants of the field work in South Africa and the Council for Geoscience of Cape Town for managing the field logistics. We especially thank the Karoo farmers for granting us access to their land and for warm hospitality. The project was funded by the GeoForschungsZentrum Potsdam and the Geophysical Instrument Pool (GIPP) provided the instruments. Most of the figures were prepared in GMT - Generic Mapping Tool (Wessel and Smith, 1998). Special thanks to M.J. de Wit and C. de Beer for assisting with the geological interpretations. The manuscript benefited significantly from the detailed reviews of Mark Muller and Maarten de Wit. This is AEON contribution 40 and Inkaba yeAfrica contribution number 24 .

\section{References}

Catuneanu, O., Hancox, P.J. and Rubidge, B.S. (1998). Reciprocal flexural behaviour and contrasting stratigraphies: a new basin development mode for the Karoo retroarc foreland system, South Africa. Basin Research, 10, $417-439$

Cole, D.I. (1992). Evolution and development of the Karoo Basin. In: M. J. De Wit and I. D. Ransome (Editors). Inversion tectonics of the Cape Fold Belt, Karoo and Karoo and Cretaceous basins of Southern Africa. Balkema, Rotterdam, The Netherlands, 23-26

De Wit, M.J. and Horsfield, B. (2006). Inkaba yeAfrica Project Surveys Sector of Earth from Core to Space. EOS, 87, 113-117
Hälbich, I.W. (Compiler) (1993). Global Geoscience Transect 9. The Cape Fold Belt - Agulhas Bank transect across Gondwana Suture, Southern Africa. American Geophysical Union Special Publication, 202, 18pp.

Hole, J. A. and Zelt, B. C. (1995). Three-dimensional finite-difference reflection traveltimes. Geophysical Journal International, 121, 427-434

Johnson, M.R., Van Vuuren, C.J. Visser, J.N.J, Cole, D.I., De V Wickens, H., Christie, A.D.M and Roberts, D.L. (1997). The Foreland Karoo Basin, South Africa. In: R.C. Selley (Editor), K.J. Hsu (Series Editor), African Basins. Sedimentary Basins of the World, Elsevier, 3, 269-317.

Lindeque, A.S., Ryberg, T., Stankiewicz, J., Weber, M.H. and de Wit, M.J. (2007). Deep Crustal Seismic Reflection Experiment Across the Southern Karoo Basin, South Africa. South African Journal of Geology, 110, 419-438.

Ryberg, T., Weber, M., Garfunkel, Z. and Bartov, Y. (2007). The shallow velocity structure across the Dead Sea Transform fault, Arava Valley, from seismic data. Journal of Geophysical Research, 112, in press.

Ryberg, T., Hole, J.A., Fuis, G.S., Rymer, M.J. and Bleibinhaus, F. (2006). Tomographic Vp/Vs velocity structure of the California Central Coast Ranges, in the vicinity of SAFOD, from controlled-source seismic data. Journal of Geophysical Research, in press.

Stankiewicz, J., Ryberg, T., Schulze, A., Lindeque, A.S., Weber, M.H. and De Wit, M.J. (2007). Initial Results from the wide-angle seismic refraction lines in the Southern Cape. South African Journal of Geology, 110, 407-418.

Vidale, J.E. (1988). Finite-difference calculation of travel times. Bulletin of the Seismological Society of America, 76, 2062-2076.

Vidale, J.E. (1990). Finite-difference calculation of traveltimes in three dimensions. Geophysics, 55, 521-526

Visser, J.N.J. (1987). The Palaeogeography of part of southwestern Gondwana during the Perm-Carboniferous glaciation. Paleogeography., Palaeoclimatology., Palaeoecology, 61, 205-219.

Visser, J.N.J. (1992). Basin tectonics in southwestern Gondwana during the Carboniferous and Permian. In: M.J. De Wit and I.D. Ransome, (Editors). Inversion tectonics of the Cape Fold Belt, Karoo, and Cretaceous basins of Southern Africa. Rotterdam, Balkema, The Netherlands, 23-26

Volquardsen, U., Wilkinson, K.J., Coetzee, L.E., Steyn, J.H. (1984). Geological Map of South-West Africa, 1:1 000 000. Council for Geoscience, Pretoria, South Africa.

Wickens, H. de Villiers. (1992). Submarine fans of the Permian Ecca Group in the southwest Karoo Basin: Their origin and reflection on the tectonic evolution of the basin and its source areas. In: M. J. De Wit and I. D. Ransome (Editors). Inversion tectonics of the Cape Fold Belt, Karoo, and Cretaceous basins of Southern Africa. Balkema, Rotterdam, The Netherlands, 117-125.

Weckmann, U., Ritter, O., A. Jung., Branch, T. and de Wit, M. (2007a). Magnetotelluric measurements across the Beattie magnetic anomaly and the Southern Cape Conductive Belt, South Africa. Journal of Geophysical Research, 112, doi:10.1029/2005JB003975.

Weckmann, U., Jung, A., Branch, T. And Ritter, O. (2007b). Comparison of electrical conductivity structures and 2D magnetic modeling along two profiles crossing the Beattie Magnetic Anomaly, South Africa. South African Journal of Geology, 110, 449-464.

Wessel. P. and Smith W. (1998). New, improved version of the Generic Mapping Tools. EOS Transactions, AGU, 79, 579.

Zelt, C.A. (1998). FAST - Program package for First Arrival Seismic Tomography. Rice University, Houston, United States of America.

Zelt, C.A. and Barton, P.J. (1998). 3D seismic refraction tomography: A comparison of two methods applied to data from the Faeroe Basin. Journal of Geophysical Research, 103, 7.187-7.210.

Editorial handling: M. J. de Wit and Brian Horsfield 